\title{
Training on utilization of planted containers from used goods in two of Primary Schools (SD model Al Azhar Medan and SD Namira Medan) in North of Sumatra
}

\author{
Haryati $^{1 *}$, Ameilia Zuliyanti Siregar ${ }^{1}$, Suzanna Fitriany Sitepu ${ }^{1}$, Jamilah $^{1}$, Alida Lubis ${ }^{1}$ \\ ${ }^{1}$ Departmen of Agronomy Faculty of Agriculture, Universitas Sumatera Utara, \\ Email: atie.koto@yahoo.co.id
}

\begin{abstract}
With the holding of training on the use of used goods into a planting container for vegetable crops in the two schools (SD Model Al Azhar Medan and SD Namira), it is expected to foster creative and innovative work in science and technology capable of producing a system, design, model of goods in the form of pouring ideas or creative ideas which is original, visionary and implementative to find solutions to problems that are relevant to the environmental problems associated with agriculture. This training was carried out for 5 months (JulyNovember 2019) through several stages, starting from problem identification, location initiation, training in the provision of used goods and vegetable cultivation. Then do the practice and guidance in the field, followed by information dissemination and publicity in mass media, making you tubes from the creation of used goods from these elementary school students. Through this training, there was an increase in the knowledge and understanding of students about the processing of used goods from bottles, wood, cans, plastics, shoes, pants, oil packaging that were converted into planting containers. Then the creations are placed as a corner of the school garden. Synergy of the University of Sumatera Utara in developing superior knowledge that is beneficial has the full support of the community, especially students of SD Model Al Azhar Medan and SD Namira Medan.
\end{abstract}

Keywords: Containers, used items, primary school model, Al Azhar, Namira.

\begin{abstract}
Abstrak
Dengan diadakannya pelatihan pemanfaatan barang bekas menjadi wadah tanam bagi tanaman sayuran di Dua Sekolah (SD Model Al Azhar Medan dan SD Namira) diharapkan menumbuhkembangkan karya kreatif dan inovatif dalam Ipteks yang mampu menghasilkan suatu sistem, desain, model barang dalam bentuk penuangan gagasan atau ide kreatif yang bersifat orisinil, visioner dan implementatif untuk mencari solusi atas permasalahan yang relevan dengan masalah lingkungan yang dikaitkan dengan bidang pertanian. Pelatihan ini dilaksanakan selama 5 bulan (juli-November 2019) melalui beberapa tahap, dimulai dari identifikasi masalah, inisiasi lokasi, pelatihan pemberian materi pemanfaatan barang bekas dan budidaya tanaman sayuran. Kemudian dilakukan praktek dan bimbingan di lapangan, dilanjutkan sosialisasi informasi dan publiaksi di mass media, pembuatan you tube dari hasil kreasi barang bekas dari siswa-siswi SD tersebut. Melalui pelatihan ini diperoleh peningkatan pengetahuan dan pemahaman dari siswa-siswi tentang pengolahan barang bekas dari botol, kayu, kaleng, plastik, sepatu, celana, kemasan minyak yang dikreativitas menjadi wadah tanam. Kemudian hasil kreasi diletakkan sebagai pojok kebun sekolah. Sinergitas Universitas Sumatera Utara dalam mengembangkan ilmu yang unggul yang bermanfaat mendapat dukungan penuh dari siswa-siswi SD, khususnya siswa-siswi SD Model Al Azhar Medan dan SD Namira Medan.
\end{abstract}

Kata Kunci: Wadah, barang bekas, Sekolah Dasar model, Al Azhar, Namira.

\section{PENDAHULUAN}

\subsection{Latar Belakang}

Limbah adalah suatu sisa usaha atau kegiatan manusia, sedangkan sampah adalah sisa kegiatan sehari-hari manusia yang dideskripsikan pemerintah dalam UU No 32 Tahun 2009 tentang 
perlindungan pengolahan lingkungan hidup dan UU No 18 Tahun 2008 tentang pengolahan sampah. Menurut [1], [2], [3], sampah terbagi atas 5 kelompok sebagai berikut:

1. Sampah dari pemukiman penduduk, seperti: sampah rumah tangga, sisa pengelolaan makanan, bekas perlengkapan rumah tangga, kertas, kardus, sampah halaman, dll

2. Sampah dari pertanian dan perkebunan, seperti: jerami dan sejenisnya. Untuk sampah yang berupa pestisida dan pupuk buatan merupakan sampah khusus yang perlu perlakuan secara khusus pula supaya tidak mencemari lingkungan

3. Sampah dari perdagangan dan tempat umum, seperti: toko, pasar, warung, swalayan (garbage), sampah kering, sisa-sisa bahan bangunan.

4. Sampah dari sarana layanan siswa-siswi SD, antara lain: tempat hiburan, jalan umum, tempat layanan kesehatan, gedung dan sarana pertemuan.

5. Sampah dari industri, hasil dari proses produksi (bahan-bahan kimia serpihan/potongan bahan), perlakuan dan pengemasan produk (kertas, kayu, plastik). Sampah industri yang berupa bahan kimia dan beracun memerlukan perlakuan khusus sebelum dibuang.

Limbah, sampah dan penghasil sampah adalah beberapa istilah yang sering kita dengar. Penghasil sampah adalah setiap orang individu atau akibat dari proses alam yang menyebabkan timbunan sampah[4]. Pengolahan sampah adalah kegiatan yang sistematis, menyeluruh, dan berkesinambungan yang meliputi pengurangan dan penanganan sampah. Menurut [5], [6], Sampah yang banyak ditemukan dalam kehidupan, diantaranya adalah plastik. Plastik baru mulai menjadi komoditas sejak 65 tahun yang lalu. Namun, kini sudah ada 8,3 miliar ton plastik mendiami Bumi. Lebih dari 70 persen dari total produksinya sekarang berada dalam aliran limbah, sebagian besar dikirim ke TPA.

Pendapat [7] menyatakan bahwa daur ulang adalah mengelolah barang yang tidak terpakai menjadi barang baru. Banyak manfaat yang diperoleh dari pendaur ulangan bahan bekas yang ada di sekitar kita, seperti plastik bekas, kertas bekas, kayu bekas, dan lain-lain. Daur ulang dapat meningkatkan kreativitas, mengurangi pencemaran dan sebagainya. Berikut akan kami jelaskan beberapa manfaat yang ada dalam usaha pengelolaan sampah daur ulang. Manfaat yang diperoleh:

1. Membuka lapangan kerja. Manfaat yang paling menonjol adalah masyarakat dapat membuka lapangan kerja. Bekerja di sektor formal saat ini sempit kesempatannya. Melamar pekerjaan membutuhkan syarat tertentu. Lowongan pekerjaan sedikit, sehingga sulit mencari pekerjaan.Usaha daur ulang ini dapat membuka lapangan kerja bagi masyarakat di sektor informal. Dengan bertambahnya lapangan pekerjaan bagi masyarakat, tingkat pengangguran dapat dikurangi.

2. Meningkatkan pendapatan masyarakat. Berkreasi dari bahan bekas menjadi kerajinankerajinan tangan lalu didistribusikan kepada masyarakat dapat meningkatkan pendapatan. Apalagi bahan baku daur ulang tidak membutuhkan modal yang besar. Dalam ekonomi, usaha seperti ini dapat menekan biaya operasional dan retribusi.Sehingga pemerintah daerah lebih ringan dalam pengeluaran pengelolaan sampah. Barang daur ulang mempunyai nilai ekonomi yang menghasilkan pendapatan.Sehingga masyarakat dapat berdaya secara ekonominya. Pemberdayaan ekonomi rakyat yang dimaksud disini adalah adanya pendapatan atau penghasilan yang biasadiperolehdarihasilpenjualanbarangolah andaribahanbekasmenjadibarang yang mempunyai nilai ekonomi. Dengan memperoleh penghasilan tersebut masyarakat dapat meningkatkan kesejahteraan dan dapat memenuhi kebutuhan hidupnya.

3. Mengurangi pencemaran lingkungan. Sampah yang dibakar dan limbah pabrik dapat menyebabkan pencemaran lingkungan. Mendaur ulang sampah-sampah dan memanfaatkan limbah, dengan menjadikannya barang kerajinan dan barang-barang kreasilainnya, pencemaran lingkungan dapat dikurangi.

4. Menghemat sumber daya alam. Berkreasi dari bahan bekas dapat menghemat sumber daya alam sebagai bahan baku kebutuhan hidup manusia.Contohnya, dengan mendaur ulang kertas kita dapat mengurangi laju pengurangan jumlah pohon. 
5. Mencegah penyakit. Sampah yang menumpuk dapat menyebabkan penyakit. Dengan mendaur ulang sampah-sampah, tumpukan sampah akan berkurang. Tingkat kebersihan pun akan meningkat jika pengelolaan sampah berjalan dengan baik.

6. Menambah kreativitas dan keterampilan. Dengan berkreasi dari bahan bekas, kita akan lebih kreatif dan terampil. Kita dapat menemukan ide-ide baru yang kreatif dan inovatif dalam berkreasi. Sampah plastik dapat bertahan hingga bertahun - tahun sehingga menyebabkan pencemaran terhadap lingkungan.

Sampah plastik berbahaya jika dibakar karena menghasilkan gas yang akan mencemari udara dan membahayakan pernafasan manusia, dan jika sampah plastik ditimbun dalam tanah maka akan mencemari tanah dan air [8]. Sampah plastik berdampak negatif terhadap lingkungan karena tidak dapat terurai dengan cepat dan dapat menurunkan kesuburan tanah. Sampah plastik yang dibuang sembarangan juga dapat menyumbat saluran drainase, selokan dan sungai sehingga menyebabkan banjir. Selain itu sampah plastik yang dibakar bisa mengeluarkan zat - zat yang berbahaya bagi kesehatan manusia [9]. Peduli lingkungan merupakan sikap dan tindakan yang selalu berupaya mencegah kerusakan lingkungan alam di sekitarnya dan mengembangkan upaya upaya untuk memperbaiki kerusakan alam yang sudah terjadi [10], [11], [12]

Berdasarkan hal tersebut, tim pengabdian LPPM USU melakukan kegiatan strategis dengan "Pemanfaatan limbah plastik sebagai wadah tanam bagi tanaman Pada Dua Sekolah Dasar", yaitu SD Model Al Azhar Medan dan SD Namira Islamic School Medan untuk meningkatkan kualitas PBM (Proses Belajar Mengajar), khususnya materi Kelas V dengan memahami konsep dan melakukan praktek. Disamping itu, setiap siswa yang mengikuti pelatihan diharapkan dapat menyusun karya tulis ilmiah sekolah yang diperlombakan dan mendapat hadiah.

Dewasa ini, sampah menjadi salah satu permasalahan yang cukup sulit di tangani di Indonesia. Hal ini terjadi karena kebiasaan siswa-siswi SDsebagai konsumen yang selalu menghasilkan sampah. Oleh karena itu dengan mengubah barang bekas terutama koran atau kertaskertas bekas menjadi barang yang dapat digunakan kembali dapat membantu mengurangi pencemaran lingkungan. Kreativitas pemanfaatan barang bekas menjadi wadah media tanam adalah solusi yang cukup baik untuk mengubah sampah botol, plastik, kaleng, karet, kertas menjadi menjadi barang yang berguna kembali, bahkan memiliki nilai jual serta dapat dikreasikan menjadi barang yang mempunyai nilai estetika. Kreativitas dalam diri seseorang dapat ditumbuhkan melalui banyak cara, salah satunya yaitu dengan membuat wadah media tanam. Sampah botol, plastik, kaleng, karet, kain dan kertas dapat dibuat wadah media tanam seperti tempat tanam bunga, sayuran, dan buah-buahan. Pemanfaatan sampah botol, plastik, kaleng, karet dan kertas kertas masih jarang dilakukan di daerah yang siswa-siswi SDnya kurang memperhatikan hal-hal seperti kreativitas wadah media tanam dengan memanfaatkan sampah. Dengan adanya program kegiatan pelatihan kreativitas pemanfaatan barang bekas menjadi wadah media tanambagi siswa-siswi Sekolah Dasar (Model Al Azhar Medan dan Namira Medan) ini diharapkan siswa-siswi SD dapat meningkatkan kepedulian terhadap lingkungan dengan memanfaatkan sampah. Selain mendapatkan pengetahuan, pemahaman dan mengasah keterampilan dalam hal kreativitas serta dapat meningkatkan kesadaran terhadap lingkungan.

\subsection{Rumusan Masalah}

1. Bagaimana memberikan pengetahuan kepada siswa-siswi SD agar mau memanfaatkan barang bekas dari sampah botol, plastik, kaleng, karet dan kertas yang ada di lingkungannya?

2. Bagaimana meningkatkan pemahaman pemanfaatan barang bekas sebagai wadah media tanam melalui sosialisasi informasi dan pelatihan kreativitas kepada siswa-ssiwi SD?

3. Bagaimana memberikan pengetahuan kepada siswa-siswi SD bahwa kreasi pemanfaatan barang bekas dapat menghasilkan produk tepat guna?

\subsection{Target}


Target dari kelas pelatihan kelas adalah:

1. Memberikan pengetahuan sekaligus pelatihan kepada siswa-siswi SDModel Al Azhar Medan dan SD Namira Medan mengenai pemanfaatan barang bekas menjadi wadah media tanam.

2. Memberikan pengetahuan tentang peluang usaha yang dapat tercipta dengan adanya keterampilan membuat wadah media tanam untuk menghasilkan produk tepat guna.

3. Meningkatkan kreatifitas siswa-siswi SD Model Al Azhar Medan dan SD Namira Medan dalam pemanfaatan barang bekas.

4. Meminimalisir pencemaran lingkungan dengan memanfaatkan sampah oleh siswa-siswi SDModel Al Azhar Medan dan SD Namira Medan.

\subsection{Luaran}

Program ini sebagai bentuk pengabdian diberikan kepada siswa-siswi SDModel Al Azhar Medan dan SD Namira Medan dengan mengadakan kegiatan sosialisasi informasi dengan ceramah, pelatihan dalam upaya pemanfaatan barang bekas menjadi wadah media tanam, luaran yang diharapkan:

1. Siswa-siswi SDModel Al Azhar Medan dan SD Namira Medan diharapkan mampu dan terampil dalam membuat wadah media tanam berbahan dasar botol, plastik, kaleng, karet, kain, kertas dan memiliki kreativitas dalam memanfaatkan barang bekas.

2. Memberdayakan siswa-siswi SD agar dapat mengembangkan kreativitasnya melalui pelatihan membuat wadah media tanam yang bernilai jual sehingga dapat meningkatkan penghasilan mereka.

3. Siswa-siswi SD akan kebersihan lingkungan sehingga dapat meminimalisir dampak negatif pencemaran lingkungan.

4. Diterbitkan di artikel ilmiah Talenta Journal of Scientific Transfer (JST) Universitas Sumatera Utara

\section{METODE}

\subsection{Waktu dan Tempat Pelaksanaan}

Program Dosen Wajib Mengabdi Lembaga Penelitian dan Pengabdian (LPPM) Universitas Sumatera Utara telah dilaksanakan di dua Sekolah Dasar, yaitu Sekolah Dasar Model Al Azhar Medan pada tanggal 24 Agustus 2019, dilanjutkan ke Sekolah Dasar Namira Medan pada tanggal 3 September 2019. Kemudian dilanjutkan praktek lapangan, pembuatan proposal Lomba Karya Tulis Ilmiah (LKTI) SD selama 2 minggu, diharapkan akhir September 2019 semua proposal masuk untuk diperiksa dan dinilai. Selanjutnya pembuatan video kegiatan, publikasi di amss media dilanjutkan pembuatan draft bahan preentasi di Seminar Pengabdian Pada Acara Dies Natalis Fakultas Pertanian USU dan publiaksi di JurnalScientific Transfer (JST) Universitas Sumatera Utara sampai Oktober 2019. Pada Bulan November direncanakan Monev dan akhir November akan dilakukan laporan kegiatan dna penjilidan laporan.

\subsection{Pelaksanaan Kegiatan}

\subsubsection{Tahap Persiapan}

Sebelum melakukan Program Dosen wajib Mengabdi LPPM USU kepada Siswa-siswi dikedua SD ini, pelaksana kegiatan melakukan perijinan ke Kepala Sekolah mengenai pelaksanaan kegiatan. Kemudian melakukan persiapan tempat, alat dan bahan sekaligus materi tentang pembuatan wadah media tanamdari barang bekas.

2.2.2. Tahap Pelaksanaan 
Kegiatan Pelatihan kreasi dalam upaya pemanfaatan barang bekas menjadi wadah media tanam yang bernilai ekonomi ini akan dilaksanakan melalui beberapa tahap:

a. Sosialisasi Program

Sosialisasi program dilaksanakan setelah tahap persiapan selesai yaitu dengan melakukan pertemuan dengan siswa-siswi yang mengikuti pelatihan ini dan mensosialisasikan tentang program yang akan di laksanakan.

b. Penyampaian Materi

Pada tahap ini peserta akan diberikan materi seputar cara membuat wadah media tanamdari barang bekas seperti botol, plastik, kaleng, karet, kertas.

c. Pelatihan Kreasi

Pelatihan kreasi yaitu praktek pembuatan berbagai macam wadah media tanam yang berbahan dasar botol, plastik, kaleng, karet, kertas yang sudah tidak terpakai dengan alat dan bahan yang sudah disediakan. Praktek dilakukan oleh siswa-siswi SD yang bersangkutandidampingi tim pengabdian masyarakat. Wadah media tanam berupa botol, plastik, karet, keranjang, dan tempat untuk menyimpan barang- barang kecil.

d. Pemanfaatan Hasil

Hasil dari pelatihan kreasi yang berupa wadah media tanam seperti pot plastik gantung, keranjang, bunga sepatu dan lain-lain kemudian akan di jual olehsiswa-siswi SDtersebut dengan menciptakan peluang usaha bagi mereka untuk meningkatkan penghasilan serta melatih berwirausaha.

e. Evaluasi

Evaluasi dilakukan setelah semua tahap diatas telah terlaksana yaitu dengan meminta kritik dan saran pada peserta pelatihan kreasi mengenai pelaksanaan program.

f. Seleksi proposal LKTI SD

Seleksi proposal Lomba Karya Tulis Ilmiah (LKTI) terdiri dari administrasi, informatif, inovasi, kreatif dan ketermutakhiran isi. Juara 1,2,3, dari masing-masing perorangan di kedua sekolah akan diberikan hadiah Piala.

g. Penyusunan Laporan

Merupakan tahap akhir pelaksanaan program yaitu menyusun dan membuat laporan hasil kegiatan.

\section{HASIL DAN PEMBAHASAN}

Berdasarkan analisis situasi yang diidentifikasipada dua sekolah memiliki berbagi macam masalah dalam pemanfaaatan barang bekas dan sampah plastik yang terdapat dilingkungan SD Model Al Azhar Medan dan SD Namira Medan, diantaranya sebagai berikut: (1). Kurangnya minat dalam mengolah barang bekas/plastik; dan (2). Kurangnya keterampilan dalam mengolah barang bekas /plastik siswa-siswi SD Model Al Azhar Medan dan SD Namira Medan.

Ketua LPPM USU, Prof. Dr. Tulus, M.Si memberikan dukungan positif atas ide dan pelaksanaan kegiatan dengan pemberdayaan siswa-siswi SD dimulai dari anak usia sekolah untuk mencintai bidang pertanian. Disamping itu, konsep pembuatan karya ilmiah bagi anak Sekolah Dasar perlu diinisiasi untuk menumbuhkembangkan keinginan meneliti dan pola berpikir anakanak kita.

Tim Dosen Wajib mengabdi LPPM USU sebanyak 5 orang, terdiri dari: Dr Ir Haryati, MP sebagai Ketua Tim dengan 4 orang anggota tim, yaitu Ameilia Zuliyanti Siregar, MSc, PhD, Alida Lubis, MSi, Jamilah SP, MP dan Ir.Suzanna Fitriani Sitepu, MSi. Pelatihan dilakukan di SD Model Al Azhar Medan pada tanggal 24 Agustus 2019. Kepala Sekolah SD Model Al Azhar Medan, Hj Eriza Dahliana, S.Si, M.Si didampingi 2 guru SD Al Azhar Medan (ibu Rika Handayani, M.Pd dan ibu Lidia Kalmawaty, S.Pd) menyampaikan, "SD Model Al Azhar menyambut baik kegiatan ini. Selain memperoleh pengalaman yang bermanfaat, anak-anak juga akan termotivasi dengan hadirnya dosen-dosen hebat dari Fakultas Pertanian USU berbagi pengetahuan dan pengalamannya dalam bidang pertanian kepada anak-anak. Semoga kerjasama ini dapat terus ditingkatkan" ujarnya 
pada saat penutupan kegiatan praktek tanam di kebun sekolah diikuti sebanyak 55 siswa SD Model Al Azhar Medan.

Dr. Ir. Haryati, M.P sebagai ketua tim Dosen Mengabdi dari Lembaga Penelitian dan Pengabdian Kepada Siswa-siswi SD menyampaikan bahwa diperlukan bahan dan alat, seperti: tanah, pupuk, bibit dan benih, air, barang bekas (botol,kaleng,sepatu,dll), cangkul dan gembor. Bibit tanaman bunga dan sayuran, seperti kangkung, sawi, bayam, cabe, dan tomat dipersiapkan. Langkah selanjutnya digunakan polybag ukuran kecil sebagai media penyemaian. Masukkan tanah dan juga pupuk (perbandingan 3:1). Masukkan bibit cabe pada polybag, disapa dan disiram setiap hari.

Selanjutnya, Ameilia Zuliyanti Siregar, M.Sc,Ph.D menyampaikan materi pelatihan pemanfaatan wadah barang bekas seperti buku, cangkir teh, botol plastik, peralatan dapur bekas, bola basket, ban, elektronik jadul bekas, tas jinjing, tas kertas, rak bekas sampai pakaian seperti bra kawat, jeans bekas, sepatu bekas yang dapat dimanfaatakan sebagai wadah tanam dan di atur dipohon atau taman sekolah. Pengaturan pola tanam, pengairan, pemupukan digunakan sesuai anjuran dan takaran secara tepat guna. Gambar 1 dibawah ini mendeskripsikan kegiatan pelatihan yang dilakukan di SD Model Al Azhar Medan dan SD Namira Medan.
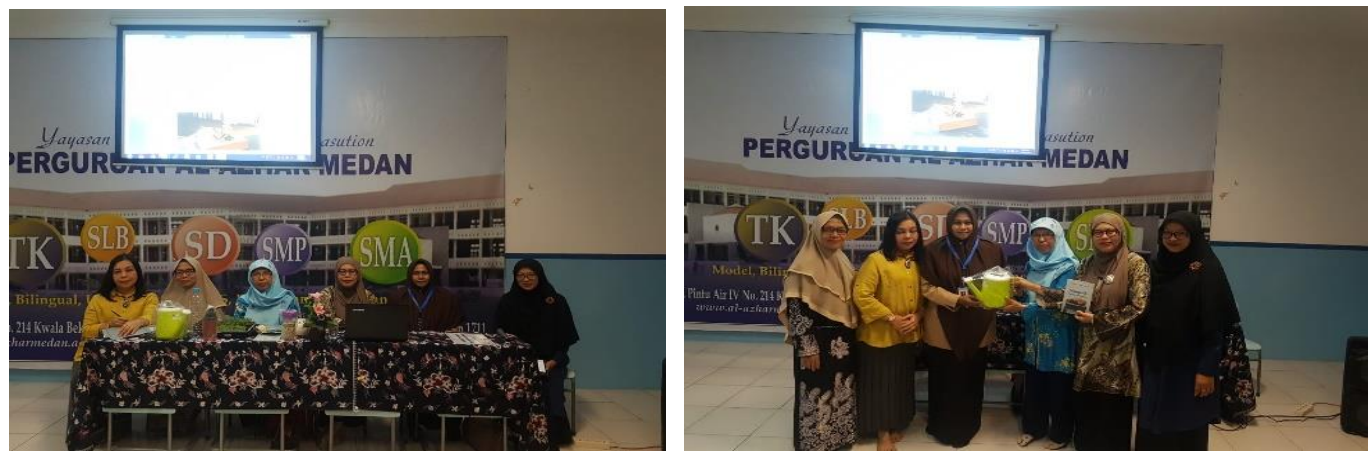

Pembukaan bersama tim pengabdian

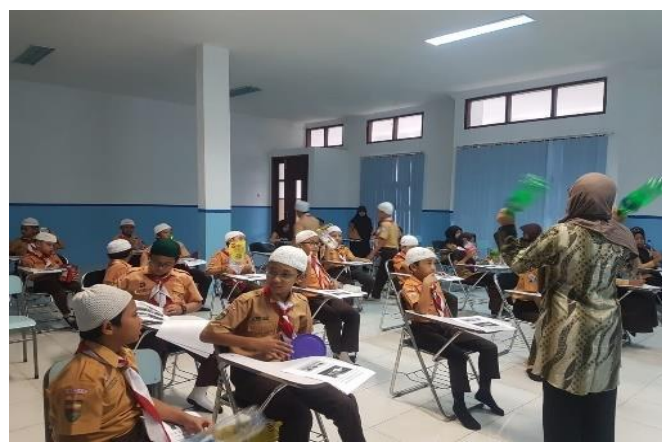

Materi pelatihan wadah media tanam
Penyerahan gembor dan buku secara simbolik

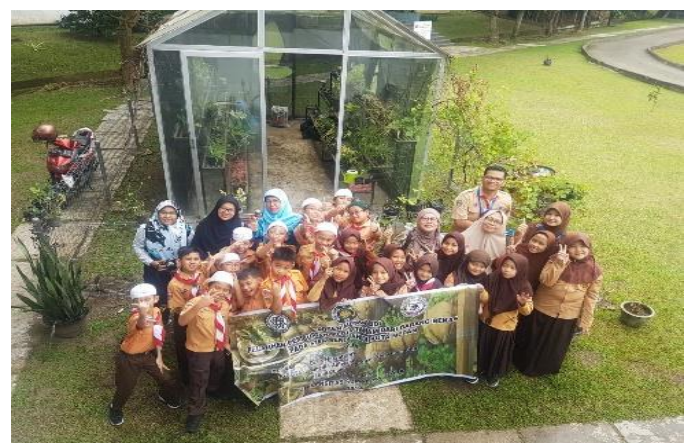

Pojok kebun sekolah

a. SD Model Al Azhar Medan 


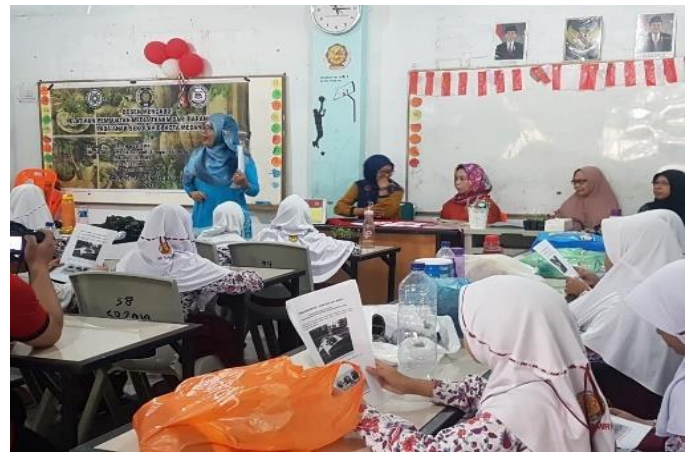

Proses pelatihan dengan materi

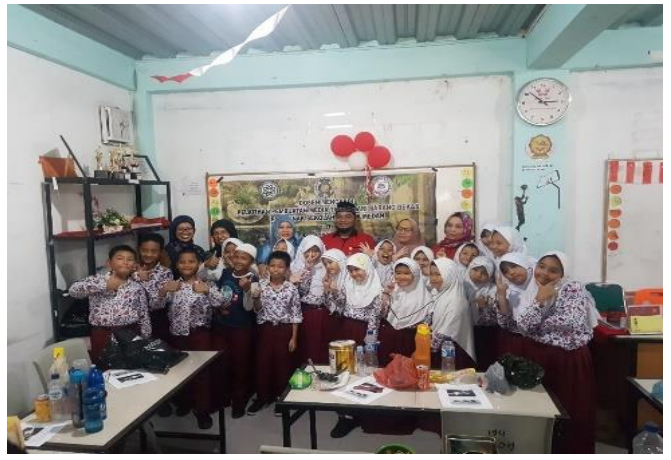

Semangat untuk ke lapangan
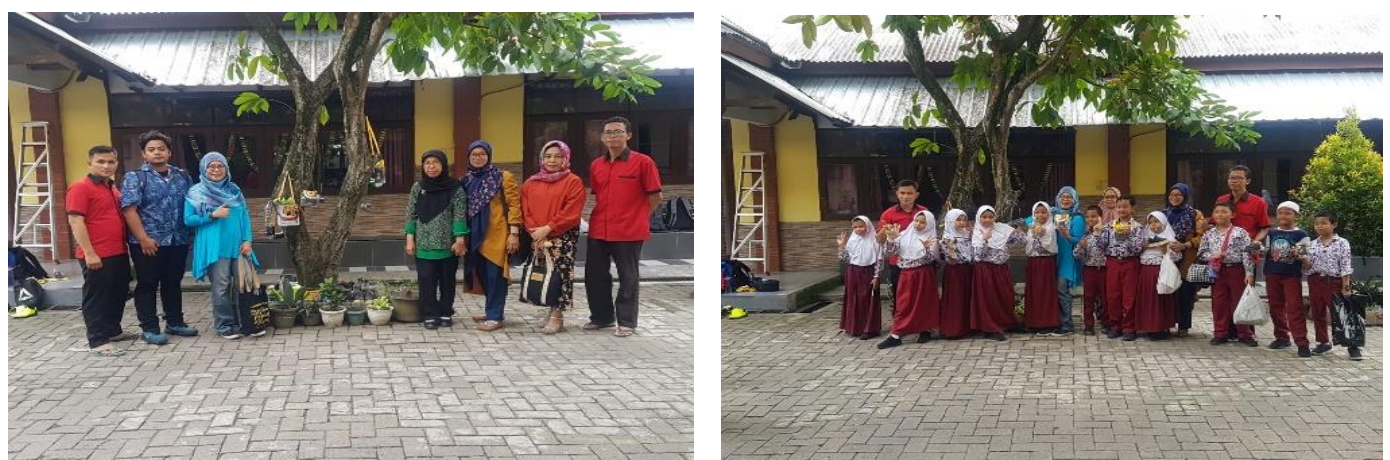

Tim komplit pengabdian dengan siswa-sisiwi dan pihak sekolah Namira di Pojok Kebun Sekolah

\section{b. SD Model Namira Medan}

Gambar 1. Proses pelatihan barang bekas jadi wadah media tanam di SD Model Al Azhar \& SD Namira Medan

H.Syafrizal, S.Pd.I sebagai Kepala Sekolah SD Namira menyampaikan "kegiatan pelatihan ini dapat menjadi pengetahuan dan dapat diaplikasikan dalam kehidupan sehari-hari siswa" pada tanggal 3 September 2019 sore kemarin didampingi Bapak Andika Saragih, SPd sebagai PKS bidang kesiswaan dan Bapak Sucipto, SPd sebagai guru Sains. Setelah dilaksanakan pelatihan dilakukan diskusi dan tanya jawab dimana anak-anak dengan antusiasnya bertanya berapa jarak tanam, berapa benih dimasukkan kedalam lubang dan bagaimana cara perawatannya. Tim pengabdian menjawab pertanyaaan anak-anak dengan memberikan hadiah diselingi games interaktif dan membimbing saat praktek dilapangan alias kebun dan taman sekolah.

Kegiatan ini berlangsung secara berkesinambungan, setelah dua minggu maka tim Dosen Mengabdi Pengabdian LPPM USU akan kemnali mendatangi dua sekolah untuk menginventarisasi, menilai dan mengumumkan juara 1,2,3 LKTI SD di 2 sekolah dan penyerahan piala secara simbolik dari tim kepada pihak sekolah dan anak yang juara direncanakan pada Selasa, 24 September 2019.

Dr. Ir. Haryati, M.P dan Ameilia Zuliyanti Siregar, M.Sc, Ph.D, kedua akademisi Universitas Sumatera Utara yang awalnya berkontribusi dalam ide pengabdian dan mengharapkan konsep pelatihan, praktek lapangan dan pembuatan karya tulis ilmiah SD akan terpola dan mendidik anak-anak mencintai bidang Sain, menumbuhkembangkan karya kreatif dan inovatif dalam Ipteks yang mampu menghasilkan suatu sistem, desain, model barang dalam bentuk penuangan gagasan atau ide kreatif yang bersifat orisinil, visioner dan implementatif untuk mencari solusi atas permasalahan yang relevan dengan bidang pertanian. Sinergitas bersama 
Universitas Sumatera Utara dalam mengembangkan ilmu yang unggul, yang bermanfaat bagi perubahan kehidupan siswa-siswi SD luas yang lebih baik.

Hasil dari bentuk dosen mengabdi LPPM USU yanf dilaksanakan kepada siswa-siswi SD berupa kegiatan pelatihan kreasi upaya pemanfaatan barang bekas menjadi wadah media tanam adalah sebagai berikut:

1. Siswa-siswi SD lebih terampil dalam membuat wadah media tanam berbahan dasar botol, plastik, kaleng, karet, kain, kertas dan memiliki kreativitas dalam memanfaatkan barang bekas.

2. Siswa-siswi SD dapat mengembangkan kreativitasnya melalui pelatihan membuat wadah media tanam yang bernilai jual sehingga dapat meningkatkan perekonomian.

3. Siswa-siswi SD sadar akan kebersihan lingkungan sehingga dapat meminimalisir dampak negatif pencemaran lingkungan.

4. Siswa-siswi SD dapat memanfaatkan pelatihan ini sebagai sarana untuk meningkatkan nilai jual sebagai salah satu daerah wisata di Sumatera Utara.

5. Diterbitkan di artikel ilmiah Jurnal Scientific of Transfer (JST) Universitas Sumatera Utara

\section{KESIMPULAN DAN SARAN}

\subsection{Kesimpulan}

Berdasarkan kegiatan pembinaan keterampilan di SD SD Model Al Azhar Medan dan SD Namira Medan dalam mendaur ulang atau mengolah barang bekas menjadi wadah media tanam diidentifikasi minat siswa menjadi lebih meningkat dari sebelumnya; (2) Keterampilan dalam mengolah barang bekas menjadi lebih baik setelah diadakan pembinaan mendaur ulang barang bekas di kedua SD tersebut mampu mengembangkan kreativitas mereka dan memanfaatkannya sebagai daya tarik pengunjung sekolah dengan membuat pojok kebun sekolah. Disamping itu, pembuatan proposal LKTI dapat merangsang minat, kreativitas dan inovasi siswa-siswi dalam menuangkan ide, gagasan dalam meneliti persoalan dan fenomena di lingkungannya.

\subsection{Saran}

Setelah melakukan pengabdian pelatihan pemanfaatan wadah media tanam, maka ada beberapa saran yang diberikan kepada siswa-siswi SDModel Al Azhar Medan dan SD Namira Medan secara luas yaitu hendaknya menumbuhkan kesadaran terhadap kebersihan lingkungan dengan memanfaatkan barang bekas menjadi barang yang berguna kembali dan bernilai jual dan menanamkan pentingnya berwirausaha sehingga siswa-siswi SD dapat menciptakan peluang usaha dengan kreativitasnya melalui pelatihan kreasi membuat wadah media tanam dari barang bekas.

\section{UCAPAN TERIMA KASIH}

Ucapan terima kasih yang sebesar-besarnya kami berikan kepada Bapak Prof Dr Tulus, M.Si sebagai Ketua dan Prof. Dr. Dra. Irnawati Marsaulina, MS, Sekretaris LPPM USU, Universitas Sumatera Utara, Ibu Hj. Eriza Dahliana, S.Si, M.Si selaku kepala sekolah SD Model Al Azhar Medan serta BapakH.Syafrizal, S.Pd.I sebagai Kepala Sekolah SD Namira yang telah banyak membantu kami dalam pelaksanaan kegiatan pengabdian ini. 
[1] Andrady, 2003.Plastic and The Environment. John Wiley \& Sons, Inc.. New Jersey.

[2] Kumar, S. dan Singh, R.K, 2011. Recovery of Hydrocarbon Liquid from Waste High Density Polyethylene by Thermal Pyrolysis. Brazilian Journal of Chemical Engineering Vol. 28, No. 04, $659-667$.

[3] Kuncoro, 2015.Memahami Arti Kode Plastik dan Penggunaannya. Dalam http://www.pasiensehat.com/2015/01/arti-kode-plastik-danpenggunaannya.html diakses pada tanggal 16 Desember 2016 pukul 15.10 WIB.

[4] Saeful Anwar, Nanang. 2008. Apa Yang Akan Kau Lakukan Terhadap Sampah.Bandung: Elisa Surya Dwitama.

[5] Arya Duta Bakar, Marshall. 2008. Mengolah Sampah Menjadi Berkah. Bandung: CV. Sarana penunjang Pendidikan.

[6] Husnul, Ade. 2008. Kreasi Mendaur Ulang Sampah. Depok: Jakarta.

[7] Apiadji, Wied Harry. 2005. Memproses Sampah. Jakarta: Penebar Swadaya.

[8] Karuniastuti, 2016.Berbagai Metode Konversi Sampah Plastik Menjadi Bahan Bakar Minyak. Jurnal Teknik. 3 (1). Hal. 32- 40.

[9] Surono, 2013. Pelatihan Pengolahan Limbah Kertas menhadi Benda Seni bagi Guru - Guru SD Jejeran Pleret Bantul. Yogyakarta.

[10] Al-Anwari, 2014. Sampah dan pengelolaanya. Materi Diklat TOT PKLH. Jakarta: Direktorat Disnaker. Universitas Negeri Yogyakarta.

[11] Tamara, Riana Monalisa. 2016. Peranan Lingkungan Sosial terhadap Pembentukan Sikap Peduli.

[12] KLHK, 2013. Kebijakan Nasional Pengelolaan Sampah. Seminar Nasional: Peran Pengusaha Daur Ulang Plastik Menuju Indonesia Bebas Sampah Tahun 2020, Jakarta 8 Oktober 2015. 